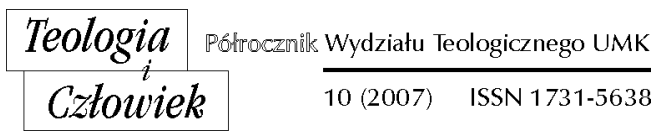

KS. MARIUSZ A. ROSZEWSKI*

OSTRAVA (REPUBLIKA CZESKA)

\title{
WIZJA WYCHOWANIA W WYMIARZE NAUCZANIA SPOŁECZNEGO PRYMASA STEFANA KARDYNAŁA WYSZYŃSKIEGO
}

\section{PSYCHODUCHOWE POTRZEBY CZKOWIEKA}

W każdym człowieku istnieje ogólne zapotrzebowanie na przyjaźń i miłość, których pragnie doświadczać w ramach określonej społeczności. Taką społecznością niewątpliwie jest rodzina, która dzięki czynnikowi emocjonalnemu łączy w sobie indywidualność ze zbiorowością. Ów czynnik sprawia, że człowiek jako jednostka angażuje się we wspólnotę całościowo, dogłębnie i trwale. W rodzinie bowiem człowiek odnajduje swoje miejsce, chcąc zaspokoić podstawowe „potrzeby związku uczuciowego, potrzeby więzi psychicznej, które rodzą przyjaźń, dają poczucie wzajemnego zrozumienia, uwalniają wreszcie od lęku przed samotnością"1. Rodzina budzi poczucie bezpieczeństwa i zaufania. Uczy otwartości, akceptacji, a przede wszystkim odpowiedzialności za innych. Pozwala doświadczyć, dzięki wzajemnemu obdarowywaniu się, że życie jest największą wartością samą w sobie. Dzięki zdrowym relacjom, których podstawą jest wzajemna akceptacja,

* Ks. Mariusz A. Roszewski (ur. 1968 r.), doktor teologii. Prowadzi badania nad osobowością rodziny $\mathrm{w}$ wymiarze personalistycznego kodeksu praw, w obszarze społecznego nauczania kardynała Stefana Wyszyńskiego.

${ }^{1}$ H. Izdebska, Przygotowanie do życia w rodzinie, Warszawa 1972, s. 48. 
życie rodzinne nabiera charakteru partnerskiego. Ów interpersonalny charakter relacji partnerskich pozwala stworzyć właściwe warunki dla zaspokojenia wciąż ewoluującej się potrzeby zaspokojenia miłości, afiliacji, bezpieczeństwa, afirmacji wielowymiarowego kontaktu, życiowego sukcesu, potrzeby rozwoju i twórczości, czy wreszcie odnalezienia sensu życia.

W ciągu całego życia wspólnotowego, w małżeństwie dochodzi do realizacji istniejącej $\mathrm{w}$ psychice człowieka potrzeby rodzicielstwa, opartej na macierzyństwie i ojcostwie. Społeczna realizacja macierzyństwa została przypisana kobiecie, która $\mathrm{w}$ istniejącym porządku społecznym, „w rodzinie - w miejscu dla siebie bezpiecznym, u boku swego męża"2, realizuje swą największą potrzebę - bycia matką, i to zarówno w wymiarze biologicznym, jak i psychicznym. Macierzyństwo sprawia, że kobieta góruje nad innymi stworzeniami i to tak dalece, że kiedy jest niezrealizowane, daje głębokie poczucie frustracji i pustki życiowej. Przeciwległym biegunem wspólnoty małżeńsko-rodzinnej różnym jednak od macierzyństwa jest ojcostwo. W przeciwieństwie bowiem do kobiety, mężczyzna nie pragnie być ojcem „za wszelką cenę". Zaspokojenie tej potrzeby związane jest raczej z chęcią założenia rodziny, opartą na szerszym, wewnętrznie zmotywowanym uczuciu, a nie potrzebą samą w sobie - bycia ojcem. Jest ona zatem realizowana na bazie jednowymiarowych motywacji, gdzie dziecko jest chciane przez ojca dla niego samego, dla dobra rodziny i rodziców. Tym właśnie sposobem zarówno specyficzny dar macierzyństwa, jak i ojcostwa spotyka się na jednej płaszczyźnie - rodzinnej, na forum której dokonuje się realizacja zarówno osobistej potrzeby obydwojga, jak również oczekiwania społecznego państwa.

\section{KULTURA WYCHOWANIA}

Kultura jest wyrazem ogólnego poziomu zachowania, która, według prymasa Stefana Wyszyńskiego, „wydobywa na światło dzienne to wszystko, co człowieka jednoczy i łączy"3; która także wpływa na szeroko rozumianą «<jakość» wychowania, której celem jest eliminowanie ze współżycia zarówno wszelkiego egoizmu, jak i indywidualizm" ${ }^{\prime 4}$. Stosunkowo pla-

\footnotetext{
2 P. Poręba, Psychologiczne uwarunkowania życia rodzinnego, Warszawa 1981, s. 24.

3 "Nie oczekujemy życia tatwego". Podczas ingresu do katedry lubelskiej, Lublin, 26 VI 946, w: Stefan kardynał Wyszyński, Prymas Polski, Nauczanie spoteczne 1946-1981, Warszawa 1990, s. 10.

4 "Głos Synodu na temat sprawiedliwości w świecie". Po powrocie z Synodu Biskupów, Warszawa, 6 I 1972, w: Stefan kardynał Wyszyński, Prymas Polski, dz. cyt., s. 482.
} 
styczna bowiem psychika młodego człowieka, jak i nieduży zasób jego doświadczeń życiowych mogą sprawić, że przyjęty w okresie dojrzewania społecznie nieakceptowany system wartości pozostawi w dorosłym już życiu, w psychice i zachowaniu takiego człowieka trwałe, często patologiczne ślady. Nieocenione zatem jest posiadanie przez rodziców wiedzy na temat organizacji i metod wychowania, a szczególnie wiedzy o psychice dziecka i warunkach jego rozwoju. "Człowiek bowiem - jak to niejednokrotnie podkreślał kardynał S. Wyszyński - to coś niesłychanie powiązanego, co przenika się wzajemnie. Przenikają się w nim moce ciała i duszy, energie fizyczne i duchowe, siły umysłu, woli i serca, najrozmaitsze dążenia zarówno osobiste, jak i społeczne, które wyprowadzają człowieka poza niego samego" ${ }^{\prime \prime}$. Zdobyta zatem gruntowna wiedza, ubogacona osobistym doświadczeniem, pozwoli na jeszcze skuteczniejsze oddziaływanie w kierunku prawidłowego kształtowania osobowości młodego człowieka.

Dzięki atmosferze wzajemnego zaufania i serdeczności, występujący $\mathrm{w}$ ramach kultury rodzinnej element emocjonalny, pozwala objąć swym zakresem psychikę dziecka. Wyrażana wzajemna życzliwość i czynna miłość, która „z serca bierze swe natchnienie i je wypowiada na dłoni”, ${ }^{\prime \prime}$ prowadzi do ukształtowania odpowiedniej więzi uczuciowej między rodzicami a dzieckiem. Źródłem sukcesu jest właściwa forma postępowania, organizacja życia w rodzinie, jego atmosfera i wytworzony styl; ; bowiem w procesie wychowania każdy krok i każde działanie ma swoje istotne znaczenie. Stanowią one zresztą modele zachowania i postępowania w późniejszym życiu. Zbudowane bowiem w młodości na zasobie doświadczeń dorosłych, umożliwiają właściwą ocenę i wybór własnych wzorów, przez co lepiej pozwalają zrozumieć swą życiową rolę wyznaczoną w społeczeństwie. Doświadczenia te mają także bezpośredni wpływ na kształt osobowości. Z kolei permanentny ich brak grozi przyjmowaniem chwilowych bodźców, nie mających nic wspólnego $\mathrm{z}$ długofalowym procesem rozwoju osobowościowego, jako coś, co ma wyznaczyć ciąg późniejszych działań. Źródłem tego typu braków jest zanik odpowiedniego klimatu wychowawczego ${ }^{8}$. Stąd

${ }^{5}$ „Z kurzem krwi bratniej...". W stulecie powstania styczniowego, Warszawa, 27 I 1963, w: Stefan kardynał Wyszyński, Prymas Polski, dz. cyt., s. 203.

${ }^{6}$ "U stóp Matki życia". Do lekarzy na Jasnej Górze, Częstochowa, 2 XII 1956, w: Stefan kardynał Wyszyński, Prymas Polski, dz. cyt., s. 72.

${ }^{7}$ Zob. Cz. Maciaszkowa, Kultura pedagogiczna rodziców, w: Pedagogika opiekuńcza. Materiaty z Krajowej Konferencji Komitetu Nauk Pedagogicznych PAN, Warszawa 1977, s. 104 n.

${ }^{8}$ Zob. A. Kamiński, Budżet czasu i jego badania, Oświata Dorosłych, nr 10 (1962); por. T. E. Olearczyk, Czas w wychowaniu, w: Jaka jesteś rodzino?, W. Kubik (red.), Kraków 1999, s. $97-98$. 
prymas S. Wyszyński często zmuszał swoich słuchaczy do zadawania sobie trudnych egzystencjalne pytań typu: „czy jako rodzicie, opiekunowie i wychowawcy wypełniamy nasze obowiązki wobec dzieci, młodzieży i chrześcijańskiego wychowania?"9 i poszukiwań na nie konstruktywnych odpowiedzi. Istnieje bowiem, jak uważał kardynał S. Wyszyński ścisły związek pomiędzy jakością życia rodzinnego a efektami wychowania.

Na jakość kultury wychowania w rodzinie ma także niemały wpływ ilość poświęconego sobie czasu. Ofiarowany drugiemu człowiekowi staje się dobrodziejstwem, bo dzięki niemu kształtuje się i rozwija osobowość młodego człowieka. Bowiem, aby życie dziecka nie stało się puste, próżne i bezwartościowe, należy już od najmłodszych lat przygotowywać je do racjonalnego wykorzystania potencjału życiowego. W praktyce prowadzi to do wykształcenia w człowieku wielu upodobań i nawyków, wpływa na charakter międzyludzkich relacji. Właściwy kierunek wyznaczają takie cechy, jak: umiejętność nawiązywania kontaktu, takt w postępowaniu, sprawiedliwość, stosowanie wysokich wymagań i konsekwencja w ich spełnianiu.

Właściwie rozumiana i przeżywana kultura wychowania rodzinnego nie tłumi, jak niektórzy uważają, samodzielności w dziecku, lecz odwrotnie - pozwala mu współuczestniczyć, $\mathrm{w}$ poczuciu odpowiedzialności za drugich, w podejmowaniu decyzji, a także uczy umiejętności oceny zarówno swych sukcesów, jak i niepowodzeń ${ }^{10}$. Rozbudzona w ten sposób aktywność wiąże dziecko emocjonalnie $\mathrm{z}$ wartościami reprezentowanymi przez rodzinę, urabia $\mathrm{w}$ nim odpowiednie postawy wobec pracy, nauki i działalności społecznej. Przez samo bycie z rodzicami i rodzeństwem, a więc z rodziną uczy się taki człowiek określonych zachowań, przez kształtowanie w sobie właściwego stosunku do szeroko pojętej moralności, zwłaszcza chrześcijańskiej, która "nie dzielac jednoczy ludzi między sobq"11. Moralność bowiem zarówno ocenia wewnętrzne potrzeby, jak i nadaje odpowiedni kształt postawom życiowym. Ta jednak nie jest możliwa poza rodziną i poza wpływem rodziny. Zatem na rodzinie spoczywa obowiązek stworzenia dziecku wartościowych pod względem wychowawczym warun-

9 "Czekamy na człowieka". Podczas uroczystości błogostawionego Wtadystawa z Gielniowa, patrona stolicy, Warszawa, 25 IX 1961, w: Stefan kardynał Wyszyński, Prymas Polski, dz. cyt., s. 187.

${ }^{10}$ Por. B. Suchodolski, Wychowanie dla przyszłości, Warszawa 1959, s. 129.

${ }^{11}$ "Pokój - pragnieniem całej rodziny ludzkiej”. Homilia w Gnieźnie, 1 I 1968, w: Stefan kardynał Wyszyński, Prymas Polski, dz. cyt., s. 340. 
ków jego rozwoju ${ }^{12}$ po to, aby kiedyś w przyszłości „cele partykularne jego działania znalazły swój wymiar w celu ostatecznym"13, jakim jest wieczność.

\section{POSŁANNICTWO WYCHOWAWCZE}

Dojrzewanie młodego człowieka dokonuje się w budzeniu i formowaniu jego woli poprzez „autorytet” rodziców, którzy są jego pierwszymi nosicielami. Polega na stwierdzeniu, że żaden ludzki czyn i postępowanie nie mogą być pozostawione własnej samowoli, nastrojowi lub namiętności, lecz są poza nimi także inne rzeczywistości i konieczności, które należy uwzględniać. Normy te sprzeciwiają się często przypadkowym dążeniom psychiki ludzkiej i muszą być zachowane wbrew temu oporowi.

W strumieniu życia wszystko jest sprzężone ze sobą i nikt nie może całkiem od nowa zaczynać, lecz musi się zakorzenić w innych ludziach, $\mathrm{w}$ ich osobistych doświadczeniach, z których przecież wyrasta. Stąd rodzice na skutek swej ludzkiej ułomnej natury stają się niestety niepełnowartościowymi nosicielami autorytetu. Owa niepełnowartość jest owocem ludzkich błędów, których źródłem jest często namiętność i stronniczość, podszyta egoizmem i samolubstwem. Ale właśnie od takich ludzi - swych rodziców, dziecko ma uczyć się żyć i działać w grupie społecznej i to według ściśle określonych przez społeczeństwo norm i zasad. Sytuacja jednak do końca nie pozostaje beznadziejna. Wyjściem jest empatia, otwarcie na drugich, czego rodzice - ucząc się sami - uczą swe dzieci. Ukazanie bowiem dziecku siebie, jako osoby potrafiącej mimo licznych różnic kochać innych, w sposób rozumny, wierny i pełny życzliwości; osoby, której zależy na dobru drugich, stanowi najlepszy sposób na zbudowanie i w dalszej kolejności utrwalenie swego autorytetu w służbie dzieła dobrego wychowania. Samo bowiem wychowanie jest i pozostanie prawdziwą "sztuką nad sztukami". Jego bowiem zadaniem jest celowe i planowe oddziaływanie na młode pokolenie $\mathrm{w}$ zamiarze podniesienia ich świadomości na wyższy stopień wyodrębnienia moralnego. Słowa: celowe i planowe wskazują, że proces wychowania wymaga długiego czasu i rzetelnego wysiłku, który polega

${ }^{12}$ Katechizm Kościoła Katolickiego uczy, że rodzice, uczestnicząc w miłości i ojcostwie samego Boga, przekazują życie i miłość swoim dzieciom. To rodzicielstwo jest dla nich równocześnie źródłem prawa i obowiązku wychowania swojego potomstwa, których rodzice nie mogą się zrzec. Zob. Katechizm Kościoła Katolickiego, nr 2221, Poznań 1994, s. 506.

13 "Prymat osoby nad rzecza". Z okazji 30 rocznicy powstania Wydziatu Filozofii Chrześcijańskiej KUL, Lublin, 7 III 1976, w: Stefan kardynał Wyszyński, Prymas Polski, dz. cyt., s. 716 . 
m.in. na wyrazistym uświadomieniu sobie przez obydwoje rodziców olbrzymiej wagi ciążących na nich wymogów wychowawczych. Zadanie to bowiem nie należy do łatwych. By mu podołać, powinny najpierw między samymi małżonkami rozwijać się: miłość, szacunek i wzajemne zaufanie. Dążąc do ukazania swemu dziecku wyższego poziomu stanu moralnego, muszą wpierw sami posiąść niezłomne zasady, takie jak: świadomość celów czy środków wychowawczych, stając się ludźmi o pełnowartościowych charakterach $^{14}$.

Myśląc o przyszłości swego dziecka, rodzice muszą w proces wychowania wdrażać swe dziecko już od chwili jego poczęcia; przy czym ów pierwszy etap będzie bardziej dotyczył ich samych - ich wzajemnych relacji. Na stopniu najniższym (po przyjściu dziecka na świat), choć - jak wskazuje psychologia - najważniejszym, ogranicza się on niejako z samej konieczności do stałej i bacznej obserwacji oraz roztropnego usuwania wszystkich zauważonych ujemnych stron usposobienia, jak m.in. rodzącego się już w tym okresie egocentryzmu bądź zaobserwowanego u dziecka nadpobudliwego temperamentu $-\mathrm{z}$ jednej strony, a jednocześnie $\mathrm{z}$ drugiej trzeba wspierać i umacniać te działania, które będą dobrze rokować na przyszłość. Przed dojściem do lat rozeznania (między 6 a 7 rokiem życia) należy przede wszystkim wyrobić $\mathrm{w}$ dziecku dobre przyzwyczajenia, utrwalić szlachetne odruchy, usunąć złe nawyki. Jak widać, sam przebieg procesu wychowania $\mathrm{w}$ rodzinie ma charakter ciągły, który wymaga od opiekunów przede wszystkim cnoty roztropności, w zróżnicowanym postępowaniu wobec wrodzonych właściwości dziecka.

Wraz z osiągnięciem wieku rozeznania $\mathrm{w}$ proces wychowania dziecka wkracza instytucja szkoły. Choć w dużym stopniu wyjmuje ona dziecko spod niemal wyłącznego do tej chwili wpływu wychowawczego rodziców, to jednak żadną miarą go nie znosi i znieść nie może. W ostatnim etapie wychowawczym w życie dziecka wnika potężny czynnik weryfikacji - życie. Jest ono zwykle nauczycielem i wychowawcą bardzo kosztownym i bezwzględnym. Posługuje się metodą doświadczenia i nieubłaganych konsekwencji każdego czynu dojrzewającej lub dojrzałej osoby. Do niego też najczęściej należy weryfikacja prawdziwych lub błędnych metod wychowania, zastosowanych niegdyś przez dom rodzinny czy szkołę.

$\mathrm{Na}$ dokonującą się socjalizację dziecka bez wątpienia ogromny wpływ ma jakość małżeństwa jego rodziców. Różnego rodzaju stresy rodzinne,

${ }^{14}$ Por. J. Winkowski, Ogniwo $i$ gniazdo. Rozważania o rodzinie $i$ wychowaniu, Sandomierz 1997, s. 45-48. 
wynikające $\mathrm{z}$ nieprzystosowania małżeńskiego rodziców, powodują zaburzenia $\mathrm{w}$ procesie jego socjalizacji. Można zauważyć tu pewną prawidłowość. Otóż dziecko pochodzące z małżeństwa, które przeżywa trudności natury emocjonalnej, ma znacznie częściej trudności ze sprawowaniem kontroli nad swoim postępowaniem i przejawia tendencję do nieposłuszeństwa. Zdaniem Tadeusza Rostowskiego: „tylko w rodzinach o wysokim poziomie jakości małżeńskiej, w których dziecko jest w pełni akceptowane, traktowane z życzliwością, wyrozumiałością, kwalifikowaną stanowczością władzy, rozwój osobowości dziecka i związany z nim proces socjalizacji może przebiegać prawidłowo"15. I odwrotnie - w przypadku małżeństw konfliktowych, gdzie rodzice przeżywają niezadowolenie z własnego związku, często odpowiedzialne za ten stan rzeczy staje się właście dziecko. Wynikiem takiego stanu rzeczy jest obecna na różnych płaszczyznach ich życia, także płaszczyźnie rodzinnej, niekontrolowana agresja, często tak ślepa, że nie pozwala ona w sposób właściwy na wypełnianie obowiązków rodzicielskich. Owocem tego jest zaburzenie całego procesu socjalizacji dziecka. Stąd winno się dążyć do osiągnięcia $w$ pełni dojrzałych postaw $w$ wewnętrznych relacjach rodzinnych, po to, aby wykształtować w dziecku zdrową osobowość.

„Postawy” są istotnym czynnikiem kształtującym właściwy obraz własnej osoby. Ma na to wpływ emocjonalny stosunek rodziców do dziecka, który wyraża się w każdym „słowie” i „,czynności”, które są źródłem konkretnych zachowań. Należy pamiętać, że u podłoża niewłaściwych postaw rodzicielskich leży na ogół nadmierny dystans uczuciowy wobec dziecka, który charakteryzuje się dużym ograniczeniem kontaktu. Rodzice stają się obojętni, powściągliwi, nie przejawiają swoich uczuć. W efekcie prawie każdy kontakt z dzieckiem sprawia im więcej rozczarowań, zawodów, urazów, przykrości i niezadowolenia, niż satysfakcji i radości. Wydaje się wtedy, że takie dziecko staje się bardziej dla swych rodziców ich życiową porażką niż darem samym w sobie.

Zachowania rodziców nacechowane demonstrowaniem negatywnych uczuć, powodują zaburzenia rozwoju emocjonalnego i przystosowawczego w dziecku, które wobec takich zachowań swych opiekunów, staje się bardziej sfrustrowane i lękliwe. Taka postawa rodzicielska wywołuje przykre konsekwencje i wpływa niekorzystnie na sam proces socjalizacji dziecka,

\footnotetext{
${ }^{15}$ Cyt. za: T. Rostowska, Transmisja międzypokoleniowa $w$ rodzinie $w$ zakresie wybranych wymiarów osobowości, Łódź 1995, s. 107-108.
} 
gdyż z punktu widzenia społecznego kształtuje w nim niewłaściwe cechy jego własnej osobowości ${ }^{16}$.

Sprzyjające prawidłowemu przebiegowi procesu socjalizacji są postawy związane z kształtowaniem się pozytywnego kontaktu z dzieckiem, którego obrazem jest „akceptacja”. Postawa ta charakteryzuje się przyjęciem przez rodziców dziecka takim, jakim ono jest przez okazanie mu sympatii i miłości. Kontakt z nim daje im zadowolenie, gdzie starają się poznać jego potrzeby i w pełni je zaspokoić, pozwalając mu jednocześnie na uczuciową niezależność, aby w ten sposób wykształtować w nim poczucie bezpieczeństwa i sensu własnego istnienia. Współdziałanie rodziców w dziele wychowania, świadczy o pozytywnym ich nastawieniu i sprawia, że dziecko czuje się równoprawnym członkiem rodziny, dzięki czemu odczuwa wewnętrzną potrzebę brania współodpowiedzialności w dziele budowania nie tylko własnej przyszłości, ale i swych najbliższych ${ }^{17}$.

\section{ClĄGłOŚĆ, PLANOWOŚĆ, KONSEKWENCJA}

Ksiądz prymas S. Wyszyński zakładał, że to, co sami rodzice przejęli od swych rodziców, i co zbudowali własnym trudem życiowym, wszystko to działa $\mathrm{w}$ większym lub mniejszym natężeniu także $\mathrm{w}$ cielesnym bycie ich dziecka. Rodzicielskie doświadczenie ma wpływ na sferę psychiczną dziecka, na jego przyszłość, na środowisko, którego w przyszłości będzie kreatorem. Uważał, że istotnym czynnikiem, który ma bezpośredni wpływ na jakość rozwoju psychicznego dziecka, jest "geniusz" jego rodziców. Według Prymasa, wyraża się on w okazywanej życzliwości, uwadze, niezawodności, pięknie czy czułości. Z drugiej strony biskup S. Wyszyński wciąż zadawał sobie pytanie czy będzie ów rodzicielski geniusz możliwy do urzeczywistnienia? Spoglądając bowiem na tempo życia społecznego, na nieustanne zabieganie, na chroniczny brak czasu kardynał S. Wyszyński lękał się, że dziecko nie doświadczy owego daru pełności w rodzinnym gronie i że później już w życiu dorosłym nie nastąpi jego wyrównanie, w efekcie czego decydująca o ,jakości” życia sfer taktu i subtelności, czyli świat „uczuć”

${ }^{16}$ Przyczyny zagrożeń jedności rodziny. Zob. B. Lachowska, Dziecko wobec przemian życia rodzinnego - analiza wybranych aspektów socjologicznych i psychologicznych, w: $W$ świecie dziecka, B. Lachowska, M. Grygielski (red.), Lublin 1999, s. 11-12.14.

${ }^{17} \mathrm{Z}$ socjologicznego punktu widzenia sens życia jest odnoszony do takiego systemu wartości, który można uznać za charakterystyczny dla pewnej grupy czy zbiorowości lub za rozpowszechniony w danym środowisku społecznym. Jest to sens w świetle społecznie uznanych wartości. 
i „wartości” pozostanie zamkniętym obszarem osobistego doświadczenia. Tymczasem to właśnie na tym filarze rzeczywistości cielesno-psychicznej wznosi się niepowtarzalna budowa „duchowa”, która jest źródłem „obyczajowej wierności i społecznej moralności"18.

Prymas S. Wyszyński, głosząc nauki społeczne, przypominał, że proces wychowania moralnego przenika ludzkie osobowe , ja" ${ }^{\prime 19} \mathrm{~W}$ życiu dziecka jest okresem szczególnym i niepowtarzalnym. Do owego wzrostu dochodzi w środowisku rodzinnym, we wspólnocie małżeńskiej opartej na miłości i wolnym wyborze dwojga ludzi, mężczyzny i kobiety, którzy odpowiadając za siebie rodzą i wychowują następne pokolenia. Zdaniem Prymasa, „wychowanie” dokonuje się w określonej przestrzeni, i to przestrzeni psychicznej naznaczonej i ograniczonej pewnymi znakami zakazu i nakazu, jako bariery zabezpieczającej, która nie pozwoli inaczej się zachować czy postąpić, niż tego wymagają przyjęte normy i społeczne zasady.

Mówiąc wielokrotnie o dojrzałości rodzicielskiej, ksiądz S. Wyszyński przypominał, że $\mathrm{w}$ dziecku normy moralne i zasady postępowania nie wynikają ze świadomej orientacji osoby, czy z jego dobrowolnego wyboru. Są one ukazane mocą rodzicielskiego autorytetu. Dzięki właściwej postawie ojca i matki, będących wzorem zachowania, dziecko uczy się podporządkowywać owym wymaganiom, zgodnie z zasadami reprezentowanymi przez swoich rodziców, nie z lęku przed ewentualną kara, czy z chęci zdobycia uznania, ale ze względu na okazywany im szacunek. Jego działanie identyfikuje go bardziej z osobą niż z zaistniałą sytuacją. Dziecko bowiem nie ocenia warunków zdarzenia, motywów, jakimi ktoś się kierował w danej sytuacji. Bierze natomiast pod uwage jedynie to, czy pewne zachowania są "zgodne" lub "nie" z nakazem lub zakazem rodziców, bądź innych ludzi dorosłych, pod których opieką aktualnie przebywa. Zatem uwzględnia ono realne skutki swego czynu i prawdopodobieństwo zdarzeń.

Ksiądz kardynał S. Wyszyński, widząc rzesze rodziców, trudzących się $\mathrm{w}$ dziele wychowania gratulował im, podnosząc często na duchu i wlewając w ich serca „nadzieję” chrześcijańską. Myśląc o dobru dziecka stanowczo sprzeciwiał się formie tzw. „bezstresowego" wychowania. Uważał je za niewłaściwe z moralnego punktu widzenia, ponieważ trwale niszczy ono osobowość dziecka. W związku z tym nieustannie apelował do grupy tzw. współczesnych rodziców o ich opamiętanie. $W$ to miejsce zachęcał ich do pracy nad ustaleniem tak ważnych dla młodego człowieka norm po to,

\footnotetext{
${ }^{18}$ M. Rzeszewski, Domu, rodzinny domu nasz, Poznań-Warszawa 1983, s. 153.

19 Por. I. Wojnar, Teoria wychowania estetycznego. Zarys problematyki, Warszawa 1976.
} 
aby zaoszczędzić w przyszłości swoim dzieciom wielu rozczarowań, budując w miejsce wygodnictwa, "bezpieczną" przestrzeń wychowawczą. Owa „przestrzeń” daje bowiem człowiekowi szansę na mniejszą ilość późniejszego przeżycia nieprzewidzianych, a co za tym idzie i nieprzyjemnych życiowych sytuacji. Dzięki stworzonej przestrzeni dziecko uczy się zdrowych zasad wzajemnego współżycia.

Na podstawie powyższego widać, jak bardzo prymasowi S. Wyszyńskiemu zależało na zdrowym moralnie funkcjonowaniu człowieka w społeczeństwie. Sprawdzianem owej dojrzałości miało być, zdaniem Kardynała, porzucenie dziecięcego sposobu myślenia przez osiągnięcie pełnej zgodności między oceną a działaniem moralnym ${ }^{20}$.

\section{WYCHOWANIE RELIGIJNE}

Prymas S. Wyszyński wiedział, że normy moralne są przez młodzież często kontestowane. Wnioski takie zrodziły się w kontekście pastoralnych doświadczeń, które pozwoliły mu przekonać się, że w każdym człowieku istnieje potrzeba odkrycia własnego osobowego , ,ja"; odkrycia własnej zdolności do przeprowadzania krytycznych refleksji nad osobistymi przeżyciami, wejścia w głąb własnych uczuć, dążeń i myśli. Jako wytrawny duszpasterz rozumiał, że wynika to $\mathrm{z}$ wewnętrznego imperatywu poszukiwania i odnalezienia sensu i celu swego istnienia. Ów nakaz wyraża się w refleksji nad jakością celu, któremu podporządkowane są zamiary i czyny; celem jest bowiem osiągnięcie zgodność w działaniu. Doświadczenie podpowiadało Prymasowi, że człowiek, zwłaszcza młody, idący drogą życia, sam $\mathrm{w}$ sobie nie jest $\mathrm{w}$ stanie tego osiągnąć, dlatego niezbędna jest pomoc; pomoc od najbliższych, którzy przez stworzenie optymalnych warunków, pomogą przetworzyć dziecku moralną kulturę, która szerokim strumieniem wlewa się w jego ,ja", na treść i osnowę jego życia, dzięki umiejętność samodzielnego rozsądzania tego, "co było" na rzecz tego, "co jest".

Zagadnienia te były dla kardynała S. Wyszyńskiego na tyle priorytetowe, że starał się je w ciągu całego swego kapłańskiego życia całościowo

${ }^{20}$ Każda osoba potrzebuje szacunku dla siebie, miłości, akceptacji własnego ,jja”, a także wolności, aby mogła stać się wyjątkową i niepowtarzalną. Potrzebuje ona struktury, która byłaby wystarczająco bezpieczna do podjęcia ryzyka wzrostu. Będzie ona zmieniała się zgodnie $\mathrm{z}$ etapami rozwoju człowieka w pragnieniach: uczucia i uznania, akceptacji, wyzwania i stymulacji, samorealizacji i duchowości. Ta ostatnia obejmuje potrzeby miłości, troski, bycia potrzebnym, szukania prawdy, piękna i dobra. Oznacza ona życie dla czegoś większego niż własna osoba - dla Boga. 
zgłębić. Wnioski były następujące. Dla przeprowadzenia właściwego procesu wychowawczego, koniecznym stawało się najpierw „osiągnięcie przez samych rodziców wewnętrznej «gotowości» dla harmonijnego ukształtowania nowej osobowości"21, która swe praźródło ma w bogactwie Boskiej osobowości. Niezbędnym warunkiem jego przeprowadzenia było „ujęcie całego procesu wychowania kompleksowo, także z uwzględnieniem jego strony religijnej"22. Bowiem wychowanie religijne, jako jedna $z$ form samego wychowania, nie ogranicza się li tylko do udzielenia pomocy w procesie kształtowania i pogłębiania nadprzyrodzonej wiary w Boga, lecz również w pogłębianiu szacunku dla szeroko rozumianych wartości ogólnoludzkich. Każdy zatem rodzic, który jest świadom jej ważności powinien uczynić wszystko, aby pomóc swemu dziecku w osiągnięciu sprawności moralnych. Prymas S. Wyszyński był czuł doniosłości owych zadań, dlatego niestrudzenie przypominał rodzicom, zwłaszcza rodzicom chrześcijańskim, aby nauczyć dziecko szlachetnego sposobu życia, winni „pielęgnować nie tylko ciało, aby było zdrowe, ale i duszę myśląc o jej pięknie"23.

Jako uważny obserwator życia społecznego, kardynał S. Wyszyński dostrzegał u młodych rodziców niegasnący kult ciała i umysłu, kosztem licznych zaniedbań $\mathrm{w}$ sferze wychowania religijnego ich dzieci. $W$ swych licznych wystąpieniach starał się wskazywać na ten palący problem, zachęcając do poszukiwać złotego środka - „bowiem, jak wychowanie fizyczne wpływa na usprawnienie ciała, a wychowanie umysłowe na usprawnienie poznawczych uzdolnień $\mathrm{w}$ zdobywaniu wiedzy, tak wychowanie religijne ma wpływ na usprawnienie całej osobowości człowieka: jego ciała, umysłu i woli" ${ }^{24}$. Nie dziwiło zatem jego słuchaczy, że wielkie zadanie widział przed katechezą, która w każdej rodzinie powinna być źródłem dla zbudowania życia moralnego, opartego o prawdy Boże. Zdaniem Prymasa jej obecność nie powinna być efektem jakiegoś zewnętrznego przymus, czy wręcz jakiejś mody, lecz aktem w pełni świadomym i dobrowolnym, będącym efektem pragnienia „współdziałania całej rodziny w służbie wychowania człowieka"25. Źródło owego mocnego przekonania o słuszności obecności Boga

${ }^{21}$ "Będa dwoje w jednym...". Do młodych matżeństw, Dom Prymasowski w Warszawie, 27.05.1962, w: Stefan kardynał Wyszyński, Prymas Polski, Kazania i przemówienia autoryzowane, V-VII 1962, t. XI, Instytut Prymasowski, Warszawa 1962, s. 137.

${ }^{22}$ Tamże, s.137.

${ }^{23}$ "Rodzice nadeszła wasza godzina". Kazanie do matżeństw katolickich, uroczystość Najświętszej Maryi Panny na Jasnej Górze, Częstochowa, 15.08.1961, w: Stefan kardynał Wyszyński, Prymas Polski, Wielka Nowenna Tysiaclecia, t. V, Paryż 1962, s. 223.

${ }^{24}$ Tamże, s. 224. 
w rodzinie, wy-nikało z logiki, że działanie zależy od rozumu i woli człowieka. Wola bowiem to zdolność chcenia, czyli stawiania sobie celów i radowania się $\mathrm{z}$ ich osiągnięcia. Jest ona jednak uzależniona od uprzedniego poznania umysłowego, które dotyczy spostrzeżenia dobra w wymiarze potrzeby materialnej bądź duchowej. Owo spostrzeżenie czy wyobrażenie rzeczy dobrych, więc przyjemnych, pożytecznych i pięknych, wzbudza w człowieku wolę ich zdobycia, podobnie jak pojęcie umysłowe owych rzeczy pozwala na radowaniu się nimi ${ }^{26}$. Kardynał S. Wyszyński widział w tym połączeniu ogromne bogactwo, którego nie sposób jednak doświadczyć w pojedynkę, bez wzajemnego współdziałania, dzięki któremu „otrzymuje się dzieło doskonałe" ${ }^{\prime 27}$. Owo wewnętrzne przekonanie do działań wspólnotowych płynęło z pasterskiego doświadczenia, że „mimo indywidualnych zabiegów rodzicielskich, dzieło wychowania młodego człowieka było w wielu wypadkach i w wielu rodzinach nieudane ${ }^{\prime \prime 28}$. Przyczynę tego upatrywał w braku wzajemnego współdziałania małżonków, efektem czego było pozostawienie dzieci własnemu, niedojrzałemu osądowi moralnemu ich uczynków. Takie podejście, zdaniem księdza S. Wyszyńskiego, nie uczy dojrzałości i prowadzi do wypaczonych osądów własnego postępowania, będące skutkiem braku dostatecznej możności zweryfikowania zamierzeń i czynów. Niepokoić zatem Prymasa musiało takie właśnie nastawienie dorosłych, którzy najwyraźniej zapominali o tym, że postępowanie ich dzieci jest wypadkową współdziałania różnokierunkowych uczuć, sądów rozumowych i dążeń woli obydwojga rodziców, którzy dla dobra swoich dzieci powinni ze sobą wzajemnie współdziałać ${ }^{2}$.

\section{WEWNĘTRZNE „JA"}

Często do rodziców, w czasie licznych przez siebie prowadzonych rekolekcjach, prymas S. Wyszyński miał w zwyczaju mówić, że „w rozwoju moralnym człowieka najistotniejszą rolę odgrywa kształtowanie dobrego i wrażliwego sumienia" ${ }^{\prime 30}$. Zdaniem Kardynała, na sumienie „wrodzone”,

\footnotetext{
${ }^{25}$ S. Wyszyński, Zasady wspótpracy w wychowaniu, Ład Boży, nr 31 (1946), s. 3.

${ }^{26}$ Zob. F. W. Bednarski, Wychowanie młodzieży dorastającej, Warszawa 2000, s. 162.

${ }^{27}$ "Będa dwoje w jednym...", s. 137.

28 Tamże, s. 138.

29 Por. tamże, s. 137.

30 "Rodzice nadeszła wasza godzina"..., s. 225.
} 
będące głosem ludzkiej rozumnej natury, nakładają się w ciągu życia pewne struktury psychiczne, które bądź sprzyjają prawidłowemu rozwojowi sumienia "wrodzonego", bądź go zniekształcają. Wraz z nim wspólistnieje sumienie "nabyte", w którym znajduje się część nieświadoma (głębia), tzw. „superego" oraz świadoma. Owe „superego" tworzy się w dziecku pod wpływem oddziaływań wychowawczych rodziców, i to w pierwszych latach jego życia. Treścią jego są podświadome lub nieświadome zapisy oddziaływań wychowawczych w postaci nakazów, ocen, norm oraz poglądów moralnych, które dziecko włącza w siebie, w tzw. internalizujący system samokontroli. Owa „internalizacja” ma ogromny wpływ na jakość kontaktów z otoczeniem a wyraża się konkretnym rodzajem zachowania. „Zatem - jak przekonywał często swych słuchaczy kardynał S. Wyszyński - ukształtowane sumienie zarówno w swej części nieświadomej, jak i świadomej wywiera $\mathrm{w}$ ciągu życia poważny wpływ na kształtowanie się sumienia wrodzonego, którego wpływ może być pozytywny lub negatywny"31.

Jeżeli normy „superego", a więc sumienia nabytego pod wpływem oddziaływań rodziców we wczesnym okresie życia dziecka są pozytywne i zgodne $\mathrm{z}$ obiektywnymi wymogami moralności, to wówczas harmonizują i korelują z głosem sumienia wrodzonego, co z kolei jest warunkiem dla prawidłowego rozwoju sumienia pojętego integralnie, jako zespołu wpływów pochodzących zarówno z wewnątrz, jak i z zewnątrz na środowisko społeczne ${ }^{32}$. Zatem "główna rola rodziców w procesie wychowawczym sumienia dziecka polega na oddziaływaniu psychicznym $\mathrm{w}$ takim stopniu, by podawane zasady moralne były zapisami wspomagającymi rozwój jego chłonnego sumienia wrodzonego" ${ }^{\prime 33}$.

31 "Bez ofiar i wyrzeczeń nie ma zwycięstw”. Ku czci Matki Bożej Zwycięskiej, Parafia Bożego Ciała na Kamionku w Warszawie, 16.08.1970, w: Stefan kardynał Wyszyński, Prymas Polski, Kazania i przemówienia autoryzowane, VI-VIII 1970, t. XXXIV, Instytut Prymasowski, Warszawa 1970, s. 205.

${ }^{32}$ Kształtowanie sumienia, dokonujące się pod wpływem nakazów i zakazów, pochodzących od rodziców, a przede wszystkim od ojca. Występuje ono w stopniu zadowalającym wtedy, gdy między nim a dzieckiem istnieją silne i pozytywne więzi uczuciowe; kiedy ojciec chętnie i dużo przebywa $\mathrm{z}$ dzieckiem i nawiązuje $\mathrm{z}$ nim żywe kontakty. Warunkiem dodatkowym jest, by ojciec sam posiadał w oczach dziecka autorytet moralny, tzn. by osobiście przestrzegał tych norm i zasad postępowania, których zachowania domaga się od swojego dziecka.

${ }^{33}$ S. Styrna, Znaczenie wychowania w rodzinie, Ateneum Kapłańskie, R. 62: 1970, t. 75 , s. 99 . 
Prymasa bardzo niepokoiło zjawisko laicyzacji, które niosło ze sobą zeświecczenie życia wielu chrześcijan ${ }^{34}$. Było to zjawisko bardzo spektakularne. Trend ten, nie zaprzeczał bowiem wprost istnieniu Boga, tylko starał się udowodnić a nawet racjonalnie tłumaczyć współczesnemu człowiekowi, że jest mu On niepotrzebny. Ten brak odczuwania transcendencji stał się najgroźniejszym wrogiem rodziny; bowiem towarzysząca temu zjawisku obojętność religijna często stawała się udziałem dziecka. Wytwarzała ona szczególną wewnętrzną wszechogarniającą atmosferę domu. Skutkiem zachwiania wiary w człowieku było to, że Bóg stawał się coraz bardziej obcy. Materializm i jego idee, odrzucanie osobowego Boga, negacja wartości pochodzących $\mathrm{z}$ Jego ustanowienia a $\mathrm{w}$ efekcie zaprzeczenie istnienia duszy i jej nieśmiertelności, doprowadzały wiele rodzin na skraj moralnej przepaści ${ }^{35}$. Taki stan - zdaniem Kardynała - skrzętnie wykorzystują dzieci, które wiedzione instynktem czują, że skrępowanie obcej obyczajowości znacznie się rozluźniło, że pojęcie zła i grzechu zeszło do poziomu tego, co „wypada" lub „nie wypada" ${ }^{36}$. W konsekwencji jednak to nie Bóg stawał się niepożądany, lecz rodzice tracili wpływ wychowawczy na swoje dziecko; a przecież, jak to trafnie przepowiadał prymas S. Wyszyński: „nie ma prawdziwego wychowania bez wychowania do wolności" ${ }^{\prime \prime 3}$.

W opinii księdza S. Wyszyńskiego fundamentem prawdziwej wolności jest „sumienie", które daje o sobie znać w sytuacji, kiedy osoba poprzez świadome działanie wchodzi w konflikt $\mathrm{z}$ zasadami moralnymi. Reakcją jest poczucie winy ${ }^{38}$, negatywny stan emocjonalny, niezadowolenie

${ }^{34}$ Zob. "Ku petni człowieczeństwa". Do młodzieży maturalnej, Warszawa, 27.05.1972, w: Stefan kardynał Wyszyński, Z gniazda orląt.. Wybór przemówień, kazań i konferencji do młodzieży, Papieski Instytut Studiów Kościelnych, Rzym 1972, s. 156 n.

${ }^{35}$ Zob. "Crux - spes nostra”. Do pisarzy i literatów na zakończenie rekolekcji, Kościót św. Anny w Warszawie, 28.03.1981, w: Stefan kardynał Wyszyński, Prymas Polski, Kazania i przemówienia autoryzowane, I-V 1981, t. LXVII, Instytut Prymasowski, Warszawa 1981, s. 134.

${ }^{36}$ Zob. "Młodzieńczym dębom, na nowe Tysiaclecie, błogostawi Episkopat Polski”. Do mtodzieży akademickiej, Katedra wrocławska, 16.10.1966, w: Stefan kardynał Wyszyński, Prymas Polski, Kazania i przemówienia autoryzowane, IX-XII 1966, t. XXV, Instytut Prymasowski, Warszawa 1966, s. 237.

37 "Res sacra Homo". Kazanie na zakończenie uroczystości jubileuszowych 300-lecia śmierci św. Wincentego à Paulo, Kościót św. Piotra i Pawła w Krakowie, 27.09.1960, w: Stefan kardynał Wyszyński, Prymas Polski, Wielka Nowenna Tysiaclecia, t. V..., s. 275.

${ }^{38} \mathrm{U}$ dzieci $\mathrm{w}$ wieku 13-14 lat poczucie winy okazuje się przeżyciem intensywnym, trwałym, doznawanym zwykle $\mathrm{z}$ niesłusznym postępowaniem odczuwanym często indywidualnie i z większą świadomością. Por. B. Harwas-Napierała, J. Trempała, Wina i wstyd w starszym wieku szkolnym, Przegląd Psychologiczny, nr 34 (1991), z. 2, s. 312-313. 
czy wreszcie wstyd ${ }^{39}$. Jakby szersze światło na wypowiedź Kardynała, rzuca profesor Włodzimierz Szewczuk. Otóż zdaniem tego psychologa „dziecko uczy się właściwego zachowania zgodnego z normą swojego sumienia podobnie, jak i innych kategorii zachowań. Uczy się zakazów, nakazów, dostrzegania sprzeczności między nimi a swoim zachowaniem. Negatywnie reaguje emocjonalnie na pojawiające się $\mathrm{w}$ życiu sprzeczności, a ponadto uczy się rozumienia skutków popełnionego czynu oraz ponoszenia odpowiedzialności za to, co zrobiło. Poznaje sposób wartościowania tych czynów, oceniania samego siebie, a także postanowienia poprawy"40. W praktyce oznacza to, że dla dziecka „dobrem" i „złem” są rzeczywistości określane przez rodziców. Wszelkie ich sądy i opinie szczególnie, jeżeli są często powtarzane i potwierdzane przykładem i sankcjami, chcąc nie chcąc zapadają głęboko w świadomość wychowanka a nawet zapisują się $\mathrm{w}$ jego odruchach. Zatem sumienie budzi się i urabia tak samo pod wpływem wielkich wydarzeń, jak i najmniejszych drobiazgów. Zdaniem profesora W. Szewczuka „drobne fakty z życia codziennego, bardziej niż lekcje moralności, dają rodzicom okazję do kształtowania prawidłowych sądów o rzeczach postrzeganych i doświadczanych, na co dzień" ${ }^{\prime 41}$. Pomocą, o czym zapewne przekonało się wielu rodziców, może być u dziecka na przykład wieczorny rachunek sumienia, który pozwala uwzględnić nie tylko negatywną stronę minionego dnia, ale niepowtarzalną okazję do powzięciu dobrego postanowienia na dzień następny ${ }^{42}$. Pomoc wydaje się niezbędna, ponieważ sporo czasu musi upłynąć, zanim dziecko przestanie utożsamiać prawo moralne $\mathrm{z}$ autorytetem i władzą rodzicielską; gdy zrozumie, że źródłem tego prawa nie są oni, lecz Bóg. Będzie zatem jemu tym łatwiej przejść

39 „Uczucie «wstydu» pojawia się w sytuacjach, w których dochodzi do przekroczenia normy, a także w zakresie umiejętności społecznych i niepowodzeń spowodowanych niezręcznym zachowaniem się, które wiąże się z niesprawiedliwym skrzywdzeniem innych. Okazuje się, że u dzieci w przedziale wiekowym 13-14 lat poczucie wstydu w odróżnieniu od winy jest doznawane jest mniej intensywnie, krócej. Pojawia się ono często dopiero w związku z ujawnieniem określonego zachowania osoby, a wiec później niż wina". Za B. Harwas-Napierała, J. Trempała, dz. cyt., s. 323.

${ }^{40}$ W. Szewczuk, Osiem szkiców do teorii osobowości, Warszawa 1990, s. 239.

${ }^{41}$ Tamże, s. 241.

${ }^{42}$ Rodzice powinni umożliwić swemu dziecku właściwe przeżycie poczucia winy, jakie rodzi się w jego duszy po spełnieniu złego czynu, czy też zaniedbaniu dobrego. Rodzice nie powinni tłumić czy gasić tego poczucia ani tym bardziej lekceważyć go, gdy jest ono usprawiedliwione, ale winni dać dziecku okazję do odpokutowania i do przeproszenia Boga i bliźniego, kładąc jednocześnie nacisk na konieczność unikania takich czynów lub podobnych zaniedbań w przyszłości. 
niejako na swój rozrachunek, kiedy spostrzeże, że sami rodzice podporządkowują się normom tego prawa. $\mathrm{Z}$ chwila, gdy to zrozumie autorytet przestanie być dla niego jedynym czynnikiem określającym, co „dobre” a co „złe". Stąd dziecku, od najwcześniejszych lat, należy stworzyć wyrazisty ideał moralny, który pozwoli obrać mu właściwy kierunek działania i wyrobić w sobie poczucie własnej odpowiedzialności. Niewątpliwie dla chrześcijanin tym ideałem moralnym jest sam Bóg, z którym może się człowiek spotkać po raz pierwszy na osobistej modlitwie. Doświadczenie duszpasterskie podpowiadało kardynałowie S. Wyszyńskiemu, że ,już małe dziecko może wiele skorzystać, patrząc jak rodzice modlą się, klęcząc przy jego łóżku"43. Oczywiście $\mathrm{z}$ biegiem lat dziecko będzie ich $\mathrm{w}$ tych czynnościach naśladować.

Sposób, w jaki rodzice nauczą swoje dziecko modlić się w dużej mierze ukształtuje $\mathrm{w}$ nim poczucie potrzeby Boga. Jeżeli $\mathrm{w}$ rodzinie pacierz odmawia się bez przekonania i zapału, w sposób można powiedzieć „nudny” to łatwo przewidzieć, że w umyśle dorastającego dziecka pojęcie każdego aktu religijnego będzie łączyć się z jakimś wewnętrznym przymusem. Gdy jednak dziecko zrozumie wartość, jaka może wypłynąć z osobistej modlitwy i zasmakuje się $\mathrm{w}$ niej, stanie się zdolne do nawiązywania prawdziwego kontaktu z Bogiem, do prawdziwej rozmowy z Nim. Stąd obowiązkiem rodziców, aż do chwili usamodzielnienia się dziecka jest bycie jego sumieniem ${ }^{44}$.

Myśląc z jednej strony o dobru dziecka, a z drugiej mając świadomość tego, że jego sumienie jest "materiałem" surowym, nieurobionym i nieukształtowanym, nie wolno rodzicom pozostawić dziecka bez kontroli. $\mathrm{W}$ przeciwnym razie $\mathrm{w}$ dorosłości sumienie może stać się niepewne, nieczyste $\mathrm{w}$ swym brzmieniu i prawie zawsze zawodne. Nie można zatem dopuścić, aby kształtujące się w dziecku sumienie stało się giętkie, elastyczne i zmienne - zależnie od przytrafiających się okoliczności; aby rzeczywistość zakazana nie okazała się dozwoloną a karygodna - usprawiedliwioną ${ }^{45}$. Ko-

43 "Rodzina Bogiem silna". Apel do Rodzin katolickich, Bazylika Prymasowska w Gnieźnie, 1.10.1961, w: Stefan kardynał Wyszyński, Prymas Polski, Wielka Nowenna Tysiąclecia, t. V..., s. 239-240; por.,,Prymas Polski na święto stanowe mężów", Katedra w Gnieźnie, marzec 1950, w: Stefan kardynał Wyszyński, Prymas Polski, Soli Deo - per Mariam. Zbiór pism i przemówień, Kosiński S. (red.), Czerwińsk n. Wisłą 1956, s. 123n.

${ }^{44}$ Por. J. Winkowski, Ogniwo i gniazdo..., s. 255-260; zob. M. Rzeszewski, Domu, rodzinny..., s. 152-153.

${ }^{45} \mathrm{~W}$ rozważaniach dotyczących tematu „winy” ważne jest rozróżnienie między moralną myślą a postępowaniem człowieka. Brak konkretnych rozstrzygnięć w tym zakresie może prowadzić do nieporozumień w pojmowaniu winy. Rozróżnienie między moralną myślą i postępowaniem człowieka pociąga za sobą dodatkową konieczność zastanowienia się nad rolą rozumowania moralnego $\mathrm{w}$ mechanizmach regulujących zachowanie. 
nieczne jest zatem wdrożenie w życie rodzinne elementów wychowania moralnego, które winno mieć charakter ciągłości, planowości i konsekwentności ${ }^{46}$. Głównym celem przyświecającym procesowi wychowania, winna być troska o to, aby dziecko nauczyło się dobrze myśleć i właściwie wybierać. Temu zapewne służą dobre relacje rodzinne, będące źródłem szeroko rozumianej wewnątrzrodzinnej harmonii ${ }^{47}$.

\section{ODPOWIEDZIALNOŚĆ ZA SIEBIE I DRUGICH}

Poznanie człowieka jawiło się w nauczaniu kardynała S. Wyszyńskiego jako zagadnienie podstawowe. Człowiek był przedmiotem jego częstych analiz społecznych $w$ aspekcie psychologicznym, rozpatrywany całościowo w wymiarze osobowym, bez żadnej jednostronności i wyolbrzymiania tego lub innego aspektu jego człowieczeństwa. Było to spojrzenie na osobę ludzką, według miary jej wielkości i fundamentalnych pytań towarzyszących jego budowie wewnętrznej i struktury egzystencjalnej ${ }^{48}$. Tak prowadzona refleksja pozwoliła mu widzieć człowieka, jako istotę materialno-duchową, o charakterze indywidualno-społecznym, posiadającą naturę moralno-religijną ${ }^{49}$.

W licznych rozważaniach wskazywał on na człowieka, który musi nieustannie przerabiać własną osobę, w celu uzdolnienia jej do działania, w wymiarze szeroko rozumianego "dobra" - zwłaszcza „dobra” społecz-

${ }^{46}$ Zob. "Na Nowy Rok Kościelny o chrześcijańskim wyzwoleniu człowieka”, Adwent 1961, w: Listy Pasterskie Prymasa Polski 1946-1974, Paryż 1975, s. 40-41; por. Stefan kardynał Wyszyński, Instrukcja o duszpasterstwie dzieci w wieku przedszkolnym, Gniezno, 23.04.1952, Wiadomości Archidiecezji Gnieźnieńskiej, nr 12 (1952), s. 405-411.

${ }^{47}$ Zob. R. R. Iatesta, Ojcowie. Odnowa rodziny chrześcijańskiej, Kraków 1996, s. 48; por. W. Gasidło, Z zagadnień etyki matżeńskiej i rodzinnej, Kraków 1990, s. 30.

${ }^{48}$ Zob. A. Rynio, Wychowanie młodzieży w nauczaniu kardynała Stefana Wyszyńskiego, Lublin 1995, s. 78.

${ }^{49}$ Prymas S. Wyszyński często poruszał kwestię integralnego procesu wychowania człowieka: „W formacji zasadniczym elementem będzie wysiłek, aby uspołecznić swoje właściwości osobowe i osobistą moralność. Idzie o to, by ona służyła nie tylko osobistemu szczęściu, ale i szczęściu innych. Nauczyliśmy się tak ekonomicznie patrzeć na człowieka, że mówimy tylko o jednym - o obowiązkach społecznych, ciążących na kieszeni. Nauczmy się mówić ludziom o obowiązkach społecznych, ciążących na mózgu, umyśle, sercu i woli, na naszych cnotach moralnych, na właściwościach i wartościach, które sobie wypracowaliśmy i które wypracowujemy w młodzieży. Trzeba uspołecznić nasze życie moralne i intelektualne, nasze uczucia i serca, by wszędzie pojawiła się miłość". S. Wyszyński, Problem chrześcijańskiego wychowania młodzieży, Zeszyty Naukowe KUL, t. 12: 1969, nr 2 (46), s. 14. 
nego; gdzie „jakość plonów [...] zależy od tego, kim się jest" ${ }^{\prime 50}$. Owo „stawanie się", będące częścią integralnie powiązanej ze sobą natury człowieka, domaga się ustawicznego kształtowania. W procesie tym, o czym było już wspomniane - istotną rolę odgrywa "wychowanie”. Biskup S. Wyszyński nie chciał definiować w sposób jednoznaczny, "czym ono jest". W to miejsce wolał raczej proces ten sprowadzić do jej doświadczalnej rzeczywistości, w której - jak uważał - dokonuje się kształtowanie całej osoby, a to przez doskonalenia jej indywidualności (a nie tylko gatunku) i to we wszystkich dziedzinach życia i działania człowieka. Ponadto odnajdywał wskazówki dla jego przeprowadzenia w personalizmie Jeana Maritaina i tomizmie Władysława Korniłowicza ${ }^{51}$, czym chętnie dzielił się ze swymi słuchaczami - wskazując, że "«wychowanie» jest powołaniem i szansą, jaką życie nie tylko daje człowiekowi, ale i stawia przed nim, jako zadanie do wykonania"52; gdzie osoba stanowi jego podmiot, jest jego twórcą i adresatem. Zdaniem Biskupa wymiar ten urzeczywistnia się zwłaszcza w odniesieniu do osobowego Boga, i stanowi wypadkową tej relacji do innych osób, żyjących podobnie jak on sam, w konkretnej społecznej wspólnocie. Wnioski takie formułował, wyprowadzając je z samego Bożego objawienia, które według niego $\mathrm{z}$ wielkim rozmachem ukazuje nadprzyrodzony wymiar osobowego człowieczeństwa, w odniesieniu do jego społecznego wymiaru. Będąc bowiem rzeczywistym odbiciem Boga, posiada człowiek „społeczny charakter osobowości"53, swoistego rodzaju ",instynkt" społeczny wraz z widocznymi predyspozycjami psychicznymi, niezbędnymi do właściwego życia we wspólnocie społecznej. Predyspozycje te sprawiają, że człowiek może spełniać się wśród innych ludzi. Ów wymiar "spełnienia” jest w nauczaniu kardynała S. Wyszyńskiego wszechobecny. Jest on ubogacony aktywnym pierwiastkiem wychowania, który przygotowuje człowieka do realizacji ideałów „pomocniczości”, „solidarności” i „służby”. Warunkiem owego „spełnienia”, w opinii księdza S. Wyszyńskiego, jest ład moralny, 1992, s. 24.

${ }^{50}$ Stefan kardynał Wyszyński, Boży świat. Wybór przemówień i kazań, Warszawa

${ }^{51}$ Ksiądz Władysław Korniłowicz uważany był za jednego z najlepszych tomistów $\mathrm{w}$ Polsce międzywojennej. Tomizm w jego wydaniu to nie tylko znajomość i popularyzacja tej doktryny, ale kształtowanie według niej człowieka i jego życia w wymiarze społecznym. Zob. J. Strojny, Rola Księdza Wtadystawa Kornitowicza we wspólnocie Kościota, Chrześcijanin w Świecie, R. 16: 1984, nr 5/128, s. 33.

${ }^{52}$ A. Rynio, Wychowanie młodzieży..., s. 85. 1993, s. 54.

${ }^{53}$ S. Wyszyński, Miłość i sprawiedliwość społeczna. Rozważania społeczne, Poznań 
który będąc niezbędnym czynnikiem dla utworzenia własnej, indywidualnej osobowości, stanowi także rękojmię dla pokoju wewnątrzspołecznego.

Wychowanie $\mathrm{w}$ duchu respektowania ładu moralnego, zdaniem prymasa S. Wyszyńskiego, otwiera wielkie możliwości działań zapobiegawczych, wobec zjawiska dehumanizacji społeczeństwa, jako owocu m.in. przyjęcia liberalnej wizji człowieka, gdzie prymat społeczności został postawiony ponad człowiekiem ${ }^{54}$. Stąd wiele miejsca w nauczaniu, prymasa S. Wyszyński zajmowała doniosłość roli „wartości moralnych”. Jego zdaniem, podmiotem tak moralności, jak i wychowania jest osoba ludzka, podstawową zaś zasadą i celem jednego i drugiego jest zintegrowana natura człowieka. Wskazując na osobę, podkreślał on kluczowe znaczenie wartości moralnych, które „zapewniają prawidłowe kształtowanie się zarówno psychiki, jak i ducha człowieka, który zmierza ku swemu celu, jakim jest osobowa dojrzałości" ${ }^{\prime 55}$. Proces ten starał się ukazywać w różnych jego aspektach, i to zarówno na płaszczyźnie indywidualnej jak i społecznej. Był bowiem przekonany, że jednym z warunków dobrego wychowania jest odpowiednie ukierunkowanie człowieka $\mathrm{w}$ stronę właściwie rozumianego "dobra” i „wolności”, które czynią z człowieka istotę odpowiedzialną

Naukę o „odpowiedzialności” odnajdywał w tajemnicy Trójcy, która jawiła się mu, jako przedziwny związek miłości Ojca do Syna, będąca źródłem wielkiego wyniesienia godności człowieka. Starał się stawiać drugą osobę Boską - Jezusa Chrystusa, jako wzór do naśladowania. Boga, który przyjął postać człowieka, którego obecność aktywizuje człowieka; człowieka, który pod Jego wpływem ukierunkowuje się ku rzeczom i wartościom przyrodzonym i nadprzyrodzonym, $\mathrm{z}$ uwzględnieniem ich znaczenia i hierarchii. W Jezusie widział Prymas źródło ambitnych tęsknot i pragnień człowieka. Rozumiał także, że tylko zjednoczenie z Chrystusem może dopo-

\footnotetext{
${ }^{54}$ Warto tu wspomnieć, że praktycznie od samego początku swego prymasowskiego posługiwania biskup Stefan Wyszyński spotykał się z jawną niechęcią władz. Powodem było przyjęcie chrześcijańskiego profilu wychowania człowieka. Niechęć ta często przybierała formę otwartej wrogości w postaci ataków na jego osobę. W odpowiedzi Prymas głosem całego Episkopatu Polski przypominał, że: „nauka religii jest związana z wychowaniem młodzieży polskiej. [...] Rodzina katolicka musi mieć zabezpieczone prawo do wyboru. Nie może być zmuszana do posyłania dzieci do szkół, [...] gdzie wychowanie opiera się na zasadach sprzecznych z moralnością chrześcijańską. Młode pokolenie polskie, [...] powinno być wychowane na chrześcijańskiej etyce miłości i sprawiedliwości". Cyt. za: P. Raina, Kardynat Wyszyński. Droga na Stolice Prymasowska, t. 1, Warszawa 1994, s. 172.

${ }^{55}$ S. Styrna, Znaczenie wychowania..., s. 99.

${ }_{56}$ Zob. A. Rynio, Wychowanie mtodzieży..., s. 105-106.
} 
móc w realizacji ludzkiego powołanie, jakim jest dążenie do szeroko rozumianej społecznej sprawiedliwości, braterstwa, miłości, uczciwości, zgody i pokoju.

\section{ZAKOŃCZENIE}

Ogromny wpływ na jakość wychowania mają przyjęte przez rodziców systemy wartości - odpowiednio dobrane, przemyślane i we właściwy sposób propagowane ${ }^{57}$. Niewątpliwie elementem najbardziej przekonywującym jest życie samych rodziców, ich sposób działania w konkretnych życiowych sytuacjach, a także kultura wzajemnego do siebie odnoszenia. Jakość tych czynników jest o tyle ważna, że dziecko, jak każda zresztą osoba, nie przyjmuje automatycznie podanych wzorów czy modeli, lecz wybiera takie, które mu są w stanie zapewnić maksimum rozwoju osobowościowego ${ }^{58}$.

Rodzice, którzy świadomie realizują w życiu swego dziecka proces wychowawczy, muszą pamiętać, że aby ich dziecko stało się człowiekiem odpowiedzialnym, musi nauczyć się zachowywać równowagę pomiędzy prawami i obowiązkami. By móc osiągnąć ten trudny cel, pierwszymi, którzy winni sobie stawiać wymagania, powinni być oni sami. Jest to o tyle istotne, że każdy człowiek jest ze swej natury niesłychanie czuły na wszelkie rozbieżności, fałsze czy kłamstwa, zwłaszcza te, które mają miejsce w życiu osób mu bliskich.

\section{THE PROCES OF UPBRINGING IN THE DIMENSION OF THE SOCIAL TEACHING BY PRIMATE STEFAN CARDINAL WYSZYNSKI}

\section{SUMMARY}

You cannot say about the child's "rights", without mentioning its "duties". Since that, to become responsible, mature you have to be aware of your own ways of behavior-the balance between the rights and the duties. Concerning this, the requirements that the child's supervisors want to be met, cannot be in contradiction with their own life. Therefore the young man is extremely sensitive to any divergences, which can take place between the declarations given and the experienced reality. The child acquires and follows the attitudes of its relatives only when there is a strong emotional relation-

${ }^{57}$ Zob. L. Wołoszynowa, Rozwój $i$ wychowanie dzieci w młodszym wieku szkolnym, Warszawa 1967.

${ }^{58}$ Por. M. Ziemska, Postawy rodzicielskie, Warszawa 1973, s. 57-64; zob. T. E. Olearczyk, Czas w wychowaniu..., s. 98-100. 
ship. Hence the fact of developing the good manners in the child is influenced by its parents' value-systems, which have to be suitable, premeditated and promoted in the right way. One of the convincing elements is the example given by the parents, the way of their behavior in different-not always extreme life situations, as far as their mutual treatment. It is important because of the fact that the child does not accept the patterns and the models automatically but chooses the ones that ensure it of the sense of security and emotional stability. 
